Малишев О. В., канд. техн. наук ${ }^{1}$

$(0000-0001-8327-344 X)$

Малишева Н. Р., д-р юрид. наук, професор 2

$(0000-0001-6630-227 \mathrm{X})$

Калмиков В. Г., канд. техн. наук ${ }^{1}$

(0000-0001-8928-182X)

Левчук О. В., канд. екон. наук, доцент ${ }^{3}$

(0000-0002-2827-2134)

1 - Інститут проблем математичних машин і систем НАН України, Київ;

2 - Інститут держави і права імені В. М. Корецького НАН України, Київ;

3 - Центр воєнно-стратегічних досліджень Національного університету оборони України імені Івана Черняховського, Київ

\title{
Оборонне планування на основі спроможностей в Україні: поточний стан і перспективи
}

Резюме. У статті проведено аналіз сучасного стану і перспектив розвитку інституту оборонного планування в Україні на основі спроможностей, досліджні питання правового забезпечення відповідної сфери, виокремлені проблемні питання цього процесу, надані рекомендації щодо вдосконалення методології регулювання та впровадження відповідного інституту 3 урахуванням досвіду НАТО, iз законодавством якого Україна має узгодити свою правову систему.

Ключові слова: оборонне планування; спроможності; носій спроможностей; правове регулювання; оцінювання спроможностей; DOTMLPF.

Постановка проблеми. У розвинених країнах i в міждержавних інтеграційних об'єднаннях, насамперед в НАТО, у сучасний період все більшого поширення набуває оборонне планування на основі спроможностей (ОПОС). 32017 року такий підхід до оборонного планування стартував і в Україні. I це закономірно, оскільки незворотність європейського та євроатлантичного курсу України передбачена преамбулою Конституції України. А у затвердженій 14 вересня 2020 року Стратегії національної безпеки України [1] (далі Стратегія) було декларовано, що для зміцнення особливого партнерства з НАТО та набуття повноправного членства в цій організації Україна планує: досягти у максимально стислі строки достатньої сумісності Збройних Сил України та інших складових сектору безпеки i оборони 3 відповідними структурами держав Альянсу; суттєво активізувати реформи, які необхідно впровадити 3 метою досягнення відповідності критеріям членства в НАТО. Впровадження ОПОС $є$ однією зі складових відповідних реформ.

Аналіз останніх досліджень i публікацій. Тема ОПОС в останні роки набула досить широкого резонансу у військових наукових колах. Аналізу, зокрема, піддавалися концептуальні засади ОПОС [2]; здійснювалось порівняння систем оборонного планування Збройних Сил України та державчленів НАТО $[3,4]$; піднімалися окремі питання впровадження ОПОС в Україні
$[3,4,5]$; зачіпалися деякі практичні аспекти оцінювання спроможностей [6]; ОПОС порівнювалось 3 попереднім досвідом оборонного планування в Україні $[7,8]$; ставились питання понятійнотермінологічного апарату та доцільності його вдосконалення $[9,10]$ тощо.

Хоча загалом тон більшості публікацій $\epsilon$ оптимістичним, деякі автори звертають увагу й на проблемні моменти. Це, насамперед, стосується необхідності наведення порядку у сфері термінології, що використовується $[9,10,11] . \quad$ У зв'язку 3 формуванням понятійного апарату предметної сфери, увагу науковців, зокрема, привернуло розмежування понять “спроможність” та “носій спроможності” [10,12]. До того ж у роботі [12] пропонується концептуальна модель предметної сфери щодо підтримки врахування та використання спроможностей. У цій моделі чітко розрізняються спроможності як такі: носії спроможностей номінальні -такі, що існують тільки "на папері";

носії спроможностей фактичні - такі, що реально існують, виявляють реальні спроможності, які можуть бути оцінені).

Розглянуті взаємозв'язки між цими категоріями.

У статті [7] зазначено, що “...до цього часу законодавчо не внормовано створення, функціонування та розвиток таких структур як сектор безпеки i оборони України, сил оборони, сил безпеки; відсутнє нормативне врегулювання процесу ОП у ЗС України та інших складових сил оборони, основаного на 
спроможностях; потребує уточнення категорійно-понятійний апарат, що застосовується у сфері стратегічного та оборонного планування". Немає одностайності й у підході до визначення базового поняття “планування", на чому, зокрема, акцентується увага у роботі [10], де пропонується широкий підхід до його трактування.

Позитивною подією стала спеціальна колективна монографія, присвячена оборонному менеджменту загалом [13]. Водночас, 3 огляду на важливість ОПОС i поточний стан його впровадження в Україні, увага до проблеми в наукових дослідженнях $є$ недостатньою. Крім того, на жаль, інтенсивність відповідних публікації наразі має тенденцію до зниження.

Критично оцінюючи позицію [14] щодо характеристики ОПОС як структурованого, прозорого та гнучкого процесу здійснення цілеспрямованих інвестицій в оборону держави, на жаль, доводиться констатувати, що процес впровадження ОПОС в Україні наразі ще на досяг задовільних рівнів структурованості, прозорості та гнучкості. Отже виникає нагальна потреба стимулювання наукової думки у сфері ОПОС, спрямованої не лише на схвалення та підтримання здійснюваних заходів, а насамперед - на ідентифікацію існуючих тут “больових точок” і розроблення пропозицій i концептуального опрацювання можливостей їх усунення.

Метою статті $\epsilon$ аналітичний огляд сучасного стану ОПОС в Україні, проблем i перспектив його вдосконалення з урахуванням досвіду НАТО як організації міждержавного партнерства, набуття повноправного членства у якій визначено стратегічним курсом нашої держави (п. 34 Стратегіi).

У процесі дослідження використовувались як загальнонаукові, так i конкретно-наукові методи: системноструктурного аналізу, догматичний, компаративістський, герменевтики, моделювання та ін.

\section{Виклад основного матеріалу}

Сучасний стан правового забезпечення ОПОС в Украӥні

Не існує міжнародно визнаного уніфікованого поняття "оборонне планування”. У національних законодавствах його зміст залежить від стратегічних політичних цілей кожної держави, іiі національних традицій, стану національної економіки, науково-технологічного рівня, а також належності до міждержавних інтеграційних об'єднань.

Загальні засади організації та здійснення оборонного планування в Україні формує низка законодавчих, інших нормативноправових актів і методичних документів. До того ж слід відзначити послідовне усвідомлення останніми роками законодавцем необхідності регламентації відносин щодо ОПОС. Так, якщо в спеціальному Законі "Про організацію оборонного планування" від 18 листопада 2004 року (втратив чинність на підставі Закону від 21 червня 2018 року) i згадки не було про планування на основі спроможностей, то в [15] термін "спроможності" зустрічається вже 15 разів. У нещодавно затвердженій Стратегії національної безпеки i оборони фокус спроможностей зосереджується на стратегії стримування для унеможливлення збройної агресії проти України, а посилення спроможностей Збройних Сил України, інших органів сектору безпеки i оборони розглядається одним 3 напрямів реалізації пріоритетів національної безпеки. Однак усі ці та деякі інші законодавчі акти містять лише норми-принципи та норми-цілі, але не конкретно-регулюючі положення, якими був би визначений понятійно-термінологічний апарат даної предметної сфери, регламентовані правові, організаційні та інституційні механізми ОПОС.

Визначення поняття "спроможності" знаходимо в п. 3.6.12 [16]: це здатність об'єкта отримувати вихід, який відповідатиме вимогам цього виходу. Однак це визначення носить занадто загальний характер i не орієнтує нас на розуміння алгоритмів дій щодо регламентації всіх складових ОПОС.

Не можна визнати таким, що ставить всі крапки над “i” в розумінні змісту ОПОС, і акт Міністерства оборони України (далі Міноборони) "Рекомендації 3 оборонного планування (РОП) на основі спроможностей Міністерства оборони України та Збройних Силах України" [17]. Відповідно до п. 1.2 цього документа, ОПОС $є$ одним із методів оборонного планування, особливістю якого $є$ розвиток спроможностей сил оборони для ефективної протидії загрозам i ризикам як військового, так і невійськового характеру 3 урахуванням імовірних сценаріїв розвитку кризових ситуацій на довгострокову перспективу, зазвичай на 10-15 років. Як тут декларується, ОПОС “передбачає створення, розвиток та підтримання оптимального складу необхідних спроможностей в межах наявних 
ресурсів. Матеріальні ресурси не завжди є визначальним фактором розвитку спроможностей".

Крім РОП, відносини щодо ОПОС регулюються в Україні документами: [18], [19], [20], [21], [22].

$\mathrm{He}$ можна не звернути увагу на важливий формально-юридичний аспект, а саме: крім першого 3 наведених документів, практично всі норми конкретно-регулюючого характеру у цій предметній сфері були затверджені наказами Міноборони і мають назви "методичних рекомендацій", або "рекомендацій". А, як відомо, методичні рекомендації не мають юридичної сили нормативно-правових актів (далі - НПА) і застосовуються лише суб'сктами, що входять до системи того центрального органу виконавчої влади, яким затверджено відповідний акт, у цьому випадку - Міноборони. Якщо суб'єкти, підлеглі цьому міністерству, вступають у відносини $з$ третіми особами, що не належать до системи Міноборони, ці документи не можуть розглядатись як правова підстава формування правовідносин. Адже визначальною формально-юридичною ознакою НПА, що видаються центральними органами виконавчої влади (зокрема, наказів Міноборони), є їх державна реєстрація в установленому законодавством порядку в Міністерстві юстиції України (частини 3-4 статті 15 Закону України "Про центральні органи виконавчої влади”).

Після державної реєстрації такі НПА включаються до Єдиного державного реєстру НПА і набувають відповідної юридичної сили. Водночас згідно 3 п. 5 Положення про державну реєстрацію нормативно-правових актів міністерств, органів виконавчої влади, затвердженого постановою Кабінету Міністрів України від 28.12.1992 № 731, “на державну реєстраиію не подаються акти рекомендаиійного, роз'яснювального та інформачійного характеру (методичні рекомендаиії, роз'яснення...) та ін.”. За загальним правилом такі документи мають рекомендаційний, роз'яснювальний та інформаційний характер, $\epsilon$ документами тлумачення правових норм, які містяться в НПА. Вони створюються для сприяння правореалізації, в деяких випадках - для роз'яснення специфіки застосування відповідних правових норм у тій чи іншій предметній сфері. Головна ознака методичних рекомендацій, що відрізняє їх від НПА, полягає в тому, що вони не можуть створювати нових правових норм і не можуть виходити за межі існуючого правового регулювання, породжуючи чи змінюючи правові норми, встановлені затвердженими в установленому порядку НПА.

Зважаючи на наведене, можна дійти висновку, що базове регулювання суспільних відносин щодо ОПОС має бути встановлено в спеціальному законі. Такий Закон "Про організацію оборонного планування" в Україні діяв до 21 червня 2018 року, коли він втратив чинність в зв'язку 3 прийняттям Закону України "Про національну безпеку України”. Колишній Закон визначав завдання, принципи, зміст і порядок планування у сфері оборони та координації дій органів державної влади у відповідній сфері. Втрата ним чинності була закономірною і пов'язаною 3 тим, що значна частина положень того Закону застаріла i не відповідала новому законодавству про національну безпеку. Водночас за межами правового регулювання опинився цілий пласт суспільних відносин щодо оборонного планування, хоча потреба в такому регулюванні набула ще більшої актуальності через нові підходи і необхідність узгодження 3 вимогами НАТО, зокрема приведення у відповідність до системи ОПОС. Уважаємо назрілим постановку питання щодо розроблення нового закону про оборонне планування в Україні, де, серед іншого, буде визначено понятійно-термінологічний апарат відповідної предметної сфери, встановлено інституційну систему забезпечення цієї діяльності, визначено управлінські функції кожної ланки цієї системи, координацію між ними, а також контроль за їх діяльністю, виокремлено всі форми і методи оборонного планування та визначено індикатори його ефективності, встановлено підстави юридичної відповідальності за невиконання нормативних вимог.

Проте конкретні механізми реалізації цих базових положень закону мають бути передбачені в підзаконних НПА, зокрема у тих, які будуть затверджені Міноборони. Методичні документи, які вже були попередньо напрацьовані, у певній частині можуть бути використані у процесі розроблення відповідних НПА, але виключно за умови, що такі акти пройдуть процедуру реєстрації в Мінюсті для набуття ними юридичної сили, а також 3 урахуванням усунення тих прогалин, на які ми звертаємо увагу в наступному підрозділі. 
Структурно-змістовний

аналіз методичних та інших регламентуючих документів

У розробленій на сьогодні офіційній документації щодо предметної сфери спостерігається намагання якнайширшого охоплення різних аспектів ОПОС, зокрема:

визначення мети, завдань і принципів оборонного планування [17];

уведення в обіг відповідної термінології [17];

регламентація оцінювання та розвитку спроможностей $[17,20]$;

визначення процедур здійснення

оборонного огляду [17, 22];

управління ризиками [17] тощо.

На підтримання використання програмно-проєктного менеджменту виданий окремий документ, присвячений управлінню проєктами [21], мета якого сформульована як “визначення порядку управління проєктами для забезпечення їх своєчасного виконання 3 оптимальним використанням ресурсів i досягнення цілей оборонної реформи”.

Певна увага приділяється питанням

оформлення документації, зокрема, щодо:

підготовки підсумкового документа за результатами організації оцінювання спроможностей [20];

регламентації структури i змісту підсумкового документа за результатом оцінювання спроможностей [20];

підготовки інформаційно-аналітичних, звітних та інших інформаційних документів [22];

підготовки Звіту про результати проведення оборонного огляду з урахуванням пропозицій КМУ та РНБО [22].

Цікавим за структурою є документ [22], який має додатки, що містять цілий спектр “методичних рекомендацій”: 3 опису безпекового середовища; 3 огляду спроможностей і планування сил; 3 планування ресурсів; 3 формування перспективної моделі 3С та інших складових оборони тощо - усього 10 позицій.

Характерним для цієї документації є те, що іiі численні складові не претендують на роль загального правила, а наведені як “зразок”, “приклад”. Так, у [17] маємо: формат опису спроможностей підрозділу (зразок); перелік сценаріїв застосування військ (сил), можливих завдань (приклад); єдиний перелік типових військових завдань (приклад); застосування методу багатокритеріального аналізу для прийняття раціонального рішення щодо розвитку спроможностей (приклад); визначення пріоритетності спроможностей (приклад); перелік оперативних спроможностей за кожним сценарієм (ситуацією) та визначення заходів щодо їх формування, нарощування, утримання та позбавлення (зразок).

Крім того, використовується ще один статус - “варіант", наприклад, документ [20] містить таке: опис майбутнього безпекового середовища (варіант); об'єднана оперативна концепція (варіант); функціональні групи спроможностей Збройних Сил України (варіант); концептуальне бачення (варіант); перелік заходів (варіант); логічно-ієрархічна структура спроможності (варіант); ідентифікація недоліків: запитальник (варіант).

Якщо взяти до уваги, що загальний обсяг усієї цієї документації не перевищує 250 сторінок, стає зрозумілим, що вона фактично тільки позначає аспекти, у кращому випадку стисло їх характеризує, але не містить чіткої і вичерпної інструктивної інформації.

Привертає увагу твердження, присутнє в [17]: "На відміну від планування на основі загроз, оборонне планування на основі спроможностей полягає в зосередженні зусиль не на створенні нових організаційних структур для забезпечення противаги відповідному бойовому потенціалу противника, а на розвитку спроможностей військ (сил) для ефективного виконання визначених завдань". Видається вкрай сумнівним, що планування від загроз автоматично призводить до появи нових організаційних структур, а планування на основі спроможностей появу таких структур виключає.

Центральними аспектами ОПОС
вважаємо проблеми спроможностей, визначення вимог до них та їх оцінювання.

Перший результат щодо ідентифікації спроможностей представлений у поточній версії Єдиного каталогу спроможностей [23], характерними особливостями якого є таке:

$$
\text { спроможності розподілені }
$$
функціональні групи - усього 9 груп [19]; кожна спроможність має: 1) код спроможності, яким слугує номер відповідного (під)пункту документа, 2) назву $\begin{array}{llll}\text { спроможності i } 3) \text { опис вимог до } & \end{array}$ спроможності;

опис вимог до спроможності, виконаний у термінах “здатностей”; так, наприклад: спроможність "Високоточні удари малої 
дальності” (код 4.5.1.1) розкривається через 14 “здатностей”;

спроможність “Супутниковий зв'язок”

(код 6.3.4) розкривається через 10 “здатностей”.

Деякі спроможності відрізняються високою інтегрованістю; наприклад, спроможність “Діагностика" (код 1.4.2.3) розкривається через дві здатності "1.1 Здатність організовувати..." i “1.2 Здатність проводити ...”, і остання 3 них деталізується переліком із 7 ненумерованих, тобто неідентифікованих, позицій.

Проблематичним виглядає те, що за більшість "спроможностей” фактично виступають "носії спроможностей", наприклад, “Десантний катер” (код 4.3.3.2), "Бойовий вертоліт" (код 4.8.2.6), "Морський розвідувальний пункт" (8.2.2.5).

Заради справедливості треба констатувати, що український каталог дуже схожий, наприклад, на аналогічний документ НАТО [24], хоча між ними $є$ й певні відмінності. Так, у документі НАТО:

a) функціональних груп спроможностей не 9 (як у [17]), а 7 (відсутні "забезпечення готовності військ (FORCE SUPPORT)" та "військово-політичне керівництво, управління ресурсами (CORPORATE MANAGEMENT \& SUPPORT)");

б) кожна спроможність має:

(1) код спроможності (CapabilityCode): алфавітно-цифровий дескриптор, який ідентифікує конкретну спроможність.

(2) назву

спроможності (CapabilityName): повна англомовна версія назви спроможності або назви варіантної групи.

(3) перехресні посилання на коди спроможностей (CC CrossReference): це поле визначає інші коди, які пов'язані з поточним кодом спроможності. Перехресне посилання (X-Ref) слід використовувати для ідентифікації залежностей або зв'язків між кодами.

(4) посилальні документи (Reference Docs): перелік основних довідкових документів, які стосуються поточного коду спроможності. Це можуть бути STANAG, публікації суміжних країн, концепції, керівництва тощо (відображаються лише скорочені посилання або номери STANAG). Вони стосуються останнього видання документа.

(5) зв'язок із кодами спроможностей CRR12: сюди включені коди спроможностей
CRR12, пов'язані 3 поточним кодом спроможності.

Наведемо приклад для однієї конкретної спроможності:

Capability Code: NADOCK;

Capability Name: Amphibious Operations

Projection Capability - Dock;

CC Cross Reference: NAL, NAS;

Reference Docs: STANAG 1149, 1465, 1173, 1468; ACO Force Standards Vol IV;

Linkagewith CRR12: NADOCK;

в) спроможності диференціюються за такими категоріями:

наріжні спроможності (CAPSTONE

CAPABILITY);

основні спроможності (PRINCIPAL

CAPABILITY);

допоміжні спроможності (ENABLING

CAPABILITY).

На жаль, український аналог [23] документа [24] не містить подібної інформації. Більше того, код спроможності, представлений у ньому лише номером (під)пункту, не відповідає своєму цільовому призначенню, оскільки можливе редагування документу включенням нових чи видаленням існуючих (під)пунктів неодмінно зруйнує логіку кодування спроможностей. Складається враження, що [23] із самого початку задуманий як текстовий документ, хоча ефективна його реалізація можлива лише шляхом проєктування, реалізації i використання відповідної бази даних [12], що не виключає отримання текстового документа (за необхідності).

У вітчизняних документах, які регламентують сферу ОПОС, поряд 3 поняттям “спроможностей” присутне вживання поняття "носія спроможностей”. У [17] йдеться про спроможність як про “здатність структурної одиниці сил оборони, яка є носієм спроможностей”. Відносини між спроможностями та їх носіями визначаються так: “Кожна структурна одиниця (елемент) Збройних Сил (сил оборони) може мати більш ніж одну бойову (спеціальну) спроможність, а кожна спроможність може реалізовуватися більш, ніж одною структурною (одиницею) елементом" [17].

Маючи обмежений доступ до відповідної документації НАТО, але переглянувши широкий iї масив, автори не знайшли у ньому подібної диференціації понять. Зазвичай, те, що в документах НАТО називають спроможностями, насправді $\epsilon$ номінальними носіями спроможностей (у термінології, запропонованій у [12]). 
Наприклад, навряд чи відповідає концептуальному змісту спроможності “команда превентивної медицини” ("Preventive Medicine Team, код MED-PMT") чи “важкий броньований батальйон” (“Armoured Heavy Battalion, код RM-H-BN").

Позитивно оцінюючи спробу розрізнення відповідних понять у вітчизняних регламентуючих документах, важко не помітити, що цей важливий підхід не був у них послідовно проведений. Так, у [23] спостерігається певна плутанина та змішування відповідних понять. Зокрема, поряд 3 такою спроможністю, як “Діагностика", можна бачити названі спроможностями "Бойовий вертоліт” чи “Десантний катер", що насправді слід відносити до носіїв спроможностей.

Слід зазначити, що нормативнометодична документація з ОПОС не обмежує сферу регулювання вузьким розумінням терміну "планування", серед іншого включаючи сюди таку важливу функцію, як оцінювання спроможностей. До того ж на сьогодні регламентації здебільшого піддаються процедурні аспекти оцінювання. $\mathrm{He}$ заперечуючи необхідності такого документа, як [20], присвяченого “порядку організації проведення оцінювання спроможностей”, і не применшуючи цінність інформації, яку він містить, звернемо увагу, що “за кадром" залишаються питання визначення предмета оцінювання. Що ж урешті-решт має підлягати оцінюванню: носій спроможностей, чи конкретна фактична спроможність, якою він володіє. Оцінювання кожної фактичної спроможності потребує індивідуального підходу до встановлення методики iї оцінювання. В ідеалі треба розробити повний галузевий перелік спроможностей, і для кожної з них - офіційну методику іï оцінювання.

На закриття цієї прогалини (невизначеність предмета оцінювання) у [17] уводиться поняття “базові компоненти (складові) спроможностей”. 3 першого погляду стає зрозумілим, що використовується відомий (див., наприклад, [25]) підхід до класифікації ресурсів організації (тобто носія спроможностей), позначений абревіатурою DOTMLPF: $\boldsymbol{D}$ Doctrine (доктрина - фундаментальні принципи, згідно 3 якими функціонує організація); $\boldsymbol{O}$ - Organization (організація організаційна структура, покладена в основу функціонування організаціi); $\boldsymbol{T}$ - Training (навчання, тренінг - процеси підтримки існуючих i набування нових необхідних умінь); $\boldsymbol{M}$ - Materiel (матеріальна база засоби, зокрема транспортні, інструменти, приладдя, запасні частини тощо); $\boldsymbol{L}$ Leadership (керівництво - здатність керувати); $\boldsymbol{P}$ - Personnel (персонал - співробітники, необхідні для функціонування організаціі); $\boldsymbol{F}$ - Facilities (нерухомість, що належить організації, і використовується нею). Можна сказати, що існує деякий вітчизняний досвід використання цього підходу, представлений, зокрема, у [26, 27]. Маючи, 3 одного боку, перелік спроможностей організації, а 3 іншого - цю класифікацію, можна ставити та вирішувати задачу оцінювання ступеня (якості) внеску кожного виду ресурсу на підтримання кожної спроможності, скажімо, по 10-бальній системі. Узагальнений кінцевий результат оформлюється у вигляді Матриці розподілу спроможностей за ресурсами DOTMLPF (Capability/DOTMLPF Alignment Matrix - CDAM). Однак контекст обговорюваної документації свідчить, що “базові компоненти (складові) спроможностей” розглядаються як основа оцінки спроможностей, а не їх носія. Виникає питання: чи можна ставити знак рівності між складовою носія спроможності і складовою спроможності? Це різні речі, хоча між ними й існує явний зв' язок.

Ця неясність тягне за собою інші. Наприклад, незрозуміло, чому "базові компоненти (складові) спроможностей" (DOTMLPF) не враховуються у, так званій, "логічно-ієрархічній структурі спроможності (варіант)" (Додаток 8 до [20]), “форматі опису спроможностей підрозділу" та "зразку формату опису спроможностей окремого зразка озброєння” (Додаток 1 до [17]).

На тлі невизначеності із застосуванням понять “спроможність" i "носій спроможності” дещо передчасною виглядає спроба [9] провести змістовну диференціацію між поняттями “спроможність”, “можливість”, “здатність". 3 огляду на те, що в [23] "спроможності" розкриваються через “здатності”, а приміром, цього не відбувається в [24], де “capability" розкривається через "capabilities", не будемо заперечувати актуальність цієї спроби, але нагадаємо, ця трійця - лише відображення більшої частини четвірки "Ability, Capability, Capacityand Competence" [28], i не виключено, що i "Competence" ще приверне увагу дослідників.

Висновки та перспективи подальших досліджень. У підсумку слід констатувати, що процес впровадження в Україні інституту 
ОПОС знаходиться лише на початковому етапі та характеризується, 3 одного боку, суттєвою змістовною невизначеністю, а 3 іншого - майже повною відсутністю нормативно-правової регламентації відносин у цій важливій сфері. 3 огляду на визнання хронологічного примату першого над другим, задача усунення змістовної невизначеності $€$ першочерговою для подальших наукових досліджень. За умови іiі розв'язання, відповідні результати мають бути закріплені у спеціальному законодавчому акті 3 питань оборонного планування, а механізми реалізації базових законодавчих вимог - у підзаконних НПА, зокрема у тих, що будуть затверджені Міноборони i зареєстровані в Мінюсті України.

\section{СПИСОК ВИКОРИСТАНОЇ ЛІТЕРАТУРИ}

1. Стратегія національної безпеки України “Безпека людини - безпека країни" : затв. Указом Президента України від 14.09.2020 p. № 392/2020. URL: https://www.president.gov.ua/ documents/3922020-35037 (дата звернення: 20.09.2020).

2. Єдиний перелік (каталог) спроможностей Міністерства оборони України та Збройних Сил України : затв. Мін. оборони України 28.11.2017 p. 356 c.

3. Дєнєжкін М. М. Вплив оцінювання та аналізу спроможностей на визначення заходів розвитку Збройних Сил України. Збірник наукових працьь Харківського начіонального університету Повітряних Сил. Харків, 2018 № 3 (57). С. 57-64.

4. Дєнєжкін М. М., Наливайко А. Д., Поляєв А. І. Особливості оборонного планування у державахчленах НАТО, на основі спроможностей. Збірник наукових працьь Центру воєнно-стратегічних досліджень Національного університету оборони Украӥни імені Івана Черняховського. Київ, 2017. № 2. C. 34-38. URL: http://nbuv.gov.ua/UJRN/ Znpcvsd_2017_2_8 (дата звернення: 20.09.2020).

5. Іващенко А. М., Павліковський А. К., Сівоха I. М. Концепція оборонного планування на основі розвитку спроможностей: проблеми впровадження. Збірник наукових праць Центру воєнно-стратегічних досліджень Національного університету оборони України імені Івана Черняховського. Київ, 2017. № 1 (59). С. 53-58.

6. Биченков В. В., Корецький А. А., Оксіюк О. Г., Вялкова В. І. Оцінювання спроможностей угруповань військ (сил) за функціональною групою “Застосування”. 28 с. DOI: 10.15587/1729-4061.2018.142175.

7. Наливайко А. Д., Поляєв А. I., Сівоха I. М. Генезис та розвиток оборонного планування в Україні. Сучасні інформаційні технологї̈ у сфері безпеки та оборони. Київ, 2017. № 2 (29). С. 138 143.

8. Романюк I. М. Ретроспектива розвитку системи стратегічного (оборонного) планування в
Збройних Силах України. Збірник наукових пращь BITI. Київ, 2018. № 1. С. 100-107.

9. Марко I. Ю. Аналіз понять “спроможність", “можливість” і “здатність” та пропозиції щодо їх застосування у документах сектору безпеки i оборони України. Socialdevelopment\&Security. 2018. № 3 (5). C. 76-86. URL: https://paperssds.eu/ index.php/JSPSDS/article/view/53/45 (дата звернення: 22.09.2020).

10. Хімченко О. С. Планування розвитку спроможностей ракетних військ та артилерії Збройних сил України: понятійний апарат. Збірник наукових праць Центру воєнностратегічних досліджень Національного університету оборони Украӥни імені Івана Черняховського. Київ, 2020. № 1 (68). С. 52-58.

11. Дєнєжкін М. М., Наливайко А. Д. Аналіз систем оборонного планування Збройних Сил України та країн-членів НАТО. Впровадження процесу оборонного планування у сфері оборони відповідно до євроатлантичних принципів та niдходів : зб. тез доп. наук.-практ. семінару. м. Київ, 15 червня 2017 р. Київ, 2017. С. 74-77.

12. Малишев О. В., Калмиков В. Г., Лисицький I. В. Підтримка обліку і використання спроможностей організації. Математичні машини і системи. Київ, 2020. № 3. С. 134-145.

13. Оборонна реформа: системний підхід до оборонного менеджменту : монографія / А. Павліковський, В. Фролов, Ф. Саганюк та ін. ; за заг. ред. д-ра військ. наук А. Сиротенка. Київ : НУОУ, 2020. 274 с.

14. Оборонне планування на основі спроможностей: особливості та перспективи впровадження / I. С. Руснак та ін. // Наука i оборона. 2017. № 2. С. 3-10.

15. Про національну безпеку України : Закон України від 21.06.2018 р. (з наступними змінами) URL: https://zakon.rada.gov.ua/laws/show/2469-19 (дата звернення: 18.09.2020).

16. ДСТУ ISO 9000:2015. Системи управління якістю. Основні положення та словник термінів. Київ : УкрНДНЦ, 2016. 73 с.

17. Рекомендації 3 оборонного планування на основі спроможностей в Міністерстві оборони України та Збройних Силах України : затв. Міністром оборони України 12.06.2017 р. 49 с.

18. Порядок проведення оборонного огляду Міністерством оборони, затверджений Кабінетом Міністрів України 31.10.2018 p. URL: https://zakon.rada.gov.ua/laws/show/941-2018п\#Техt (дата звернення: 18.09.2020).

19. Функціональні групи спроможностей (попередній розподіл сфер відповідальності) : затв. Міністром оборони України 28.11.2017 р. $35 \mathrm{c}$.

20. Рекомендації з порядку організації проведення оцінювання спроможностей у Збройних Силах України : затв. Міністром оборони України 07.12.2017 p. 29 c.

21. Методичні рекомендації 3 управління проєктами : затв. Міністром оборони України 20.02.2019 p. 52 c. 
22. Методичні рекомендації 3 проведення оборонного огляду : затв. Міністром оборони України 07.06.2019 p. 84 с.

23. Вишневский В. В., Малышев О. В.

Калмыков В. Г., Обобщенная оценка организационных систем. В кн. Information Modelsof Knowledge / Krassimir Markov, Vitalii Velychko, Oleksy Voloshin (ed.). Kiev; Sofia : ITHEA, 2010. C. 46-50.

24. Вишневський В. В,

Малишев О. В. Соломонов В. А. Організаційно-інформаційні технології підтримки експертної діяльності в процесах оборонного планування на основі спроможностей. У кн. “Цифрова революція в соціально-економічній сфері: історія і перспективи": зб. матеріалів VI Всеукр. наук.практ. конф. "Глушковські читання". Київ, 2017. C. 21-23.

25. Bi-SC CapabilityCodesandCapabilityStatements (CC\&S). NATO, 2016. 403 p.

26. DOD DictionaryofMilitaryandAssociatedTerms. USA. Asof January 2020. 376 p.

27. Ability, Capability, CapacityandCompetence. Blog: The Knowledge Economy. URL: https://www.businessprocessincubator.com/content/a bility-capability-capacity-andcompetence/\#: :text=A\%20Capacity $\% 20$ is $\% 20$ the $\%$ 20ability,be\%20aware $\% 20$ of $\% 20$ its $\% 20$ competence (дата звернення: 18.09.2020).

Стаття надійшла до редакційної колегії 24.11.2020

\section{Capability-based defense planning in Ukraine: current state and prospects}

\section{Annotation}

The main features and problematic issues of defense planning in Ukraine are considered in the article. Nowadays, in developed countries and in interstate integration alliances, especially in NATO, capability-based defense planning (CBDP) is becoming more widespread. Starting in 2017, this approach to defense planning has started in Ukraine as well. And this is natural, because the irreversibility of the European and Euro-Atlantic course of Ukraine is provided by the preamble of the Constitution of Ukraine. And the approved National Security Strategy of Ukraine declares that in order to strengthen the special partnership with NATO and gain full membership in this organization, Ukraine plans to: achieve in the shortest possible time sufficient compatibility of the Armed Forces of Ukraine and other components of the security and defense sector; significantly intensify the reforms that need to be implemented in order to meet the criteria for NATO membership. The implementation of CBDP is one of the components of the relevant reforms.

It should be noted that the process of implementation of the CBDP institute in Ukraine is only at the initial stage and is characterized, on the one hand, by significant substantive uncertainty, and on the other - almost complete lack of legal regulation of relations in this important area. Based on the recognition of the chronological primacy of the first over the second, the task of eliminating substantive uncertainty is a priority for further research. Subject to its resolution, the relevant results should be enshrined in a special legislative act on defense planning, and the mechanisms for implementing the basic legislative requirements - in the bylaws, including those that will be approved by the Ministry of Defense and registered with the Ministry of Justice of Ukraine. DOTMLPF.

Keywords: defense planning; capabilities; carrier capacity; legal regulation; capacity assessment; 